\title{
ORTHODOX CHURCH MUSIC IN THE CREATIVE WORK OF ITALIAN COMPOSERS OF THE SECOND HALF OF THE XVIII CENTURY AND ITS RECEPTION IN SACRED CONCERTS OF UKRAINIAN COMPOSERS
}

\section{Shumilina O. A.}

\section{INTRODUCTION}

The second half of the XVIII century in the history of Orthodox music culture was the high noon time of the choral concerto genre. This genre is well known for the creative work of composers of Ukrainian origin who worked in large cities of the Russian Empire: Maxim Berezovsky (1745-1777), Dmitry Bortnyansky (1751-1825), Artemiy Wedel (1767-1808), Stepan Degtyarev (1766-1813). Choral concerts were also written by Italian musicians who came to the Russian capital of St. Petersburg at the invitation of Catherine II. Choral works by Italian composers for the Russian Orthodox Church constitute an independent field of creativity, little known outside St. Petersburg, where their activities took place, and not thoroughly studied. Therefore, we devote this article to the study of choral works written by Italian composers for Orthodox worship, leaving aside other spheres of creative activity (composing operas and staging opera performances, organizing and conducting chamber concerts, playing harpsichord, etc.).

One of the sections is devoted to the reception of the Orthodox music of Italian composers in the works of the Ukrainian musician Maxim Berezovsky, who also worked in St. Petersburg. The connections are traced on the example of the most famous composition of M. Berezovsky - the choir concert "Ne otverzhi", which is the hallmark of the era of musical classicism of the second half of the 18th century. Despite the fame and popularity of this concert, editing issues remain poorly understood. A study of the manuscript materials of the last third of the eighteenth century testifies to the existence of the first edition of the concert created during B. Galuppi's stay in Petersburg. The wellknown version of the "Ne otverzhi" concert, which is considered to be the original author's concert, is in fact a later version prepared for publication at the beginning of the 19th century, i.e. in the time of G. Sarti. 


\section{Orthodox Church music in the creativity of B. Galuppi}

The earliest among the known samples of the classical choral concerto genre were created by Baldassare Galuppi (1706-1785) - the first Italian composer whom Catherine II specifically invited to St. Petersburg after her accession to the throne. B. Galuppi did not serve in the Court Choir, but his job was to compose a new repertoire for the Court Choir. The composer's three-year stay in Petersburg (1765-1768) and work as the first court conductor resulted in the emergence of the Liturgy and a dozen choral chants, including concerts written for Church Slavonic texts.

Galuppi was writing his sacred songs for Church Slavonic texts only for a four-voice mixed choir, as part of a soprano - alto - tenor - bass. This corresponded to the composition of the Court Choir, which accompanied church services with the participation of the first persons of the Russian Empire. Let us quote the words by the German academician Jacob von Staehlin, who lived in Russia at that time and published in $\mathbf{1 7 6 9}$ his notes on the court musical culture. He described the composition of the singing chapel in 1768 - the last year of B. Galuppi's stay in St. Petersburg, as follows: "In the past 1768 the Imperial Chapel consisted of 12 basses, 13 tenors, 13 alto s, 15 discants and almost of the same number of young students and growing up students" [9, p. 59]. Further, Staehlin writes about the repertoire of the Court Chapel, mentioning Galuppi among the authors: "Usually, during the daily church service in the court chapel, the choir sings traditional works, sometimes motets; in the presence of the Empress, as well as on Sundays and holidays, the figure Mass is always performed. But more often, and during the great holidays, always, without exception, psalms, laudatory songs and other texts are performed in the form of real church concerts, composed both by Italian court conductors, such as Manfredini, the venerable Galuppi, and Ukrainian composers, formerly court singers” [9, p. 59].

B. Galuppi's creative heritage includes practically all the genres of the Orthodox sacred music listed by J. Staehlin - traditional (everyday) works, motets, psalms, mass. This means that the Italian Kapellmeister wrote music not only for festive, but for everyday worship. Obviously, this was made by order, since in the mid-sixties the repertoire of the chapel required updating, and composers who could create it did not exist yet. Let us note that the traditional works refer to short one-part songs intended for daily performance, psalms are sacred concerts that were composed based on psalms texts, motets are the small compositions occupying an intermediate position between simple everyday songs and more complex concerts, the Mass is the Orthodox Liturgy. Concerts are the most numerous group of spiritual works created by B. Galuppi.

Not all of B. Galuppi's choral compositions are preserved until nowadays, some are known only by their names given in the catalogues and sale 
announcements of the music texts of the late XVIII and early XIX centuries. There are four such sources:

1) Catalogue of singing music text of 1793 (description of the note collection of an unknown Moscow owner, with the initial measures of each piece written out);

2) Announcement of the music texts sale in $\mathrm{H}$. Gene's store for 1804 (Moscow Gazette, 1804, No. 80 dated 5 October);

3) D. Bortnyansky widow's register for 1827, including a list of music texts left after D. Bortnyansky's death;

4) The announcement in the "St. Petersburg Vedomosti" newspaper for 1822 (No. 23 dated 21 March) [5, p. 314-326].

The description of B. Galuppi's heritage in the field of Orthodox Church music begins with the sacred concert genre. All of B. Galuppi's six concerts referred to in the sources mentioned "Vsi yazytsy vospleshchite ${ }^{1}$, "Gotovo serdtse moye, Bozhe"2, "Na Tya, Hospody, upovakh"3, "Priidite, presvetloye Khristovo", "Sudi, Gospodi, obidyashchiye mya" ${ }^{5}$, "Uslyshit tya Gospod", 6 ), to date, the music texts of only three concerts are known - "Gotovo serdtse moye, Bozhe” D-dur (in 5 parts), "Sudi, Gospodi, obidyashchiye mya” F-dur (at 5) and "Uslyshit tya Gospod"” with a-moll (in 4 parts) are written based on psalms texts. These concerts are preserved, because they were published in 1817-1818 by the Court singing chapel on the initiative of its director D. Bortnyansky ${ }^{7}$.

Each of three famous today B. Galuppi's concerts has a cyclic structure and consists of four or five parts; between the parts of the cycle tempo contrasts are formed, and fugue is the last part. It should be noted that the composition model of the concert cycle offered by the Italian Kapellmeister is quite typified, if not standard. Further, such a standard will be followed by other authors of choral concerts written in a new manner - M. Berezovsky, D. Bortnyansky and others.

The above sources provide us with the information that, in addition to the concerts, B. Galuppi wrote several one-part sacred songs for Church

${ }^{1}$ Moscow Gazette, 1804, № 80, 5 October, H. Gene’s Catalogue.

2 Ibid.; St. Petersburg Gazette, 1822, № 23, 21 March; RSHA, f. 499, d. 1, 1827, № 82 (D. Bortnyansky Widow's Register).

${ }^{3}$ Moscow Gazette, 1804, № 80, 5 October, . Gene’s Catalogue, № 9.

${ }^{4}$ Ibid.

${ }^{5}$ St. Petersburg Gazette, 1822, № 23, 21 марта; RSHA, f. 499, d. 1, 1827, № 82 (D. Bortnyansky Widow's Register).

${ }^{6}$ Catalogue of singing music text of 1793, №76 (D. Bortnyansky’s authorship); Moscow Gazette, 1804, № 80, 5 October, H. Gene’s Catalogue; RSHA, f. 499, d. 1, 1827, № 82 (D. Bortnyansky Widow's Register).

${ }^{7}$ [Галуппи Б. Услышит тя Господь в день печали / Готово сердце мое, Боже / Суди, Господи, обидящие мя / Благообразный Иосиф / Плотию уснув]. СПб., 1817-1818. 
Slavonic texts. These include "Blagoobrazny Iosif"8 and "Mironositsam zhenam", which were published in 1817-1818 as part of a single work (see footnote 7).

B. Galuppi wrote the liturgy for the Orthodox Liturgy C-dur ${ }^{10}$ and "Heruvimskaya" 11 , which is also one of the liturgical cycle parts.

B. Galuppi addresses the motet genre in his two-part composition "Plotiyu usnuv"12, which was also printed in 1817-1818 and which the researcher of the choral concert genre Marina Rytsareva defines as "motet with fugue” [7, p. 101]. In its form, this song reminds of two-part concert cycle, consisting of a slow first part and a more mobile fugue, between which there is a figurative-emotional and inverse contrast.

B. Galuppi's choral compositions were intended for the Court Choir; however, soon after Italian maestro's departure from St. Petersburg, they started to expand to other cities of the Russian Empire. Already in the seventies of the XVIII century they are included onto the manuscript singing collections and copied right up to the beginning of the XIX century, which indicates their popularity. Some collections include several B. Galuppi’s works, some have individual compositions. Among the lists the record is prevailing for individual parts, although there are also choral scores. Church Slavonic texts are written sometimes in Latin transliteration.

C-dur liturgy includes the largest number of handwritten copies recorded in eight church-singing collections. The earliest is the parts songs collection dating 1770-1772, formerly belonging to one of the monasteries of the city of Yaroslavl [5, p. 318], from which two voice books with alto and tenor parts were preserved $^{13}$. It is opened with “Orthodox Liturgy Galuppi’s” («Служба Божия Галуппиева»), parts of which are recorded by Kiev square notation.

The Kiev square notation is also used to record B. Galuppi's liturgy in the handwritten set of voice books of 1774-1785 from the Verkhovazh Cathedral of the Assumption (Verkhovazh village, Vologda Region) ${ }^{14}$ [1, p. 41, 64]. The set is incomplete, some parts are missing, and the authorship is not specified.

${ }^{8}$ RSHA, f. 499, d. 1, 1827, № 82 (D. Bortnyansky Widow’s Register).

${ }^{9}$ Ibid.

${ }^{10}$ Music texts catalogue, 1793, №108 (D. Bortnyansky’s authorship).

${ }^{11}$ Moscow Gazette, 1804, № 80, 5 October, H. Gene's Catalogue, №8.

${ }^{12}$ Music texts catalogue, 1793, №52; Moscow Gazette, 1804, № 80, 5 October, H. Gene’s Catalogue; RSHA, f. 499, d. 1, 1827, № 82 (D. Bortnyansky Widow’s Register).

${ }^{13}$ RSL, f. 218, № 882 (alto), Glinka All-Russian Museum Association of Musical Culture, ф. 283, № 643 (tenor).

${ }^{14}$ Glinka All-Russian Museum Association of Musical Culture, f. 283, № 595, 596 (альт), 602, 603 (discant), 604 (бас). 
In other manuscripts B. Galuppi's liturgy is recorded by an Italian notation. The first among them is a set of voice books from the Berlin Singing Academy (Sing-Akademie zu Berlin), which dates with the seventies of the XVIII century, and maintained now in one of Kiev's archives ${ }^{15}$ and is known as Galuppi and Berezovsky's Kiev manuscript collection [11, p. 144]. The musical text of B. Galuppi's liturgy is entered there by parts in separate voice books, and the authorship is not specified.

In the manuscript of 1780 the liturgy musical text is presented in the form of a four-part score, and the Church Slavonic text is written in Latin transliteration $^{16}$. The use of transliteration is explained by the fact that the score was probably intended for performance by the musicians of the Vienna court choir, the archive of which currently maintains the manuscript. The authorship is indicated at the top of the sheet, before the beginning of the music text ("Del Sig ${ }^{\mathrm{r}}$. Baldassar Galuppi Buranello”).

Separate parts of B. Galuppi's liturgy, without indication of authorship, are included in the songs of the incomplete manuscript set of voice books ${ }^{17}$ compiled in the eighties of the XVIII century ${ }^{18}$.

The bass part of B. Galuppi's liturgy, also without indication of authorship, is included in the manuscript of 1791, which was obtained by the Moscow archives from the Yaroslavl diocese ${ }^{19}$. It is the only voice book preserved from the once complete set of singing voices, and contains only bass parts of various choral compositions of classical style.

And, finally, a complete set of singing parts of B. Galuppi's liturgy is available in the collection of voice books of the Yaroslavl Kazan Yaroslavl Kazan at the turn of the XVIII-XIX centuries ${ }^{20}$. The record of the music text is anonymous.

In the XIX century B. Galuppi's liturgy was published several times in the collections of sacred and musical works by different authors, for the first time - after D. Bortnyansky's death, roughly in 1834 (the edition does not have the year and place of issue, but contains a choral arrangement for pianoforte, which is a dating factor) ${ }^{21}$. It should be noted that these collections had only the first two parts of the liturgy printed ("Slava Otzsu i Synu”, C-dur - 3/2 and "Yedinorodny Syne", C-dur - 4/4). Most likely, they were written by the

${ }^{15}$ Central State Archive-Museum of Literature and Art of Ukraine, f. 441, № 907.

${ }^{16}$ ÖNB, HK. 3086/3 (A Whk - VII/397).

${ }^{17}$ Glinka All-Russian Museum Association of Musical Culture, f. 283, № 256 (alto), 878, 996 (тенор), 879, 944 (бас).

${ }^{18}$ Dating refers to one of the parts of the collection, in which compositions of the early classical style are represented, including B. Galuppi; see. [10, c. 29].

${ }^{19}$ Glinka All-Russian Museum Association of Musical Culture, f. 283, № 509 (bass).

${ }^{20}$ Ibid., № 903-906.

${ }^{21}$ List of collections with B. Galuppi liturgy music texts published, see: [5, c. 315]. 
invited Italian composer, while all other parts of B. Galuppi's liturgical cycle were completed by other authors; A. Lebedeva-Yemelina suggests that $\mathrm{M}$. Berezovsky is one of them [5, p. 318]. It should be also noted that the complete cycle, which includes all the liturgy songs, is recorded only in the parts collection under the title of "Orthodox Liturgy Galuppi's” (“Служба Божия Галуппиева", see footnote 13), while the remaining musical manuscripts have only the first two parts of this liturgy.

In musical terms B. Galuppi’s liturgy is an unquestionable breakthrough in comparison with the many-choral part liturgical cycles. Its parts are more well-balanced, in some ways even simpler, especially in texture, but the purpose of this simplification was to overcome the old, heavy-handed manner of writing, which represented a retired baroque style and required updating. B. Galuppi's liturgy music is characterized by subtle modulation transitions (in the section "Slava Otzsu i Synu"), the perfection of counterpoint technique (in the section "Yedinorodny Syne"), masterful interaction of singing parties, attentive attitude to the word, with complete respect of prosody. Importance is attached to the performance aspects, especially the dynamic nuances.

B. Galuppi's Liturgy became the first completed and ready to perform composition of a new style, therefore remained popular until the end of the XVIII century, despite the appearance of a large number of liturgical cycles in the works of B. Galuppi's followers, also written in a new manner.

The next most popular among the manuscript monuments of the late XVIII century and editions of the XIX century is the two-part motet with fugue "Plotiyu usnuv". Written based on the Easter exapostilarion text, it, according to the edition of 1834, was performed "at the highest court during the Great Lent" [5, p. 322]. There are eight handwritten copies of this song in various church and singing collections. Some of them have already been named by us in connection with the fact that they contain B. Galuppi's liturgy: it is a collection from the Berlin Singing Academy of the seventies of the XVIII century (see footnote 15) and incomplete sets of voice books of 1774-1785 and the eighties of the XVIII century, maintained in one of the Moscow's archives (see footnotes 14 and 17). These collections should be added with the voice book, containing bass parts, remained from the once complete set, containing the bass part of "Plotiyu usnuv" 22, a manuscript with bass, tenor and alto parts prepared for sale on the announcement of $1804^{23}$; two complete music scores in the manuscript collections of the late XVIII century, one of which contains the author's surname («Соч: Галуппія») ${ }^{24}$; as well as the music score of 1814 with a German text, incorrectly attributed to D. Bortnyansky, whose name is

\footnotetext{
${ }^{22}$ Glinka All-Russian Museum Association of Musical Culture, f. 283, № 861.

${ }^{23}$ RSL, f. 817 , k. 14, № 11.

${ }^{24}$ RSHA, f. 1119, d. 1, № 58; f. 1119, d. 1, № 60 (authorship).
} 
inscribed in the title ("Mottetto nella Quaresima di Demetrio Bortnjanskij, Maestro di Cappella a Pietroburgo") ${ }^{25}$ [1, p. 50, 51].

This motet consists of two contrasting parts, combined by a common tonality. This includes Adagio ("Plotiyu usnuv", c-moll, 4/4) and Allegro ("Paskha netleniya", c-moll, 4/4 - fugue). This is a very solid and harmonious work; the only drawback is its brevity. The beautiful, sublime sound of the choir in the first part is emphasized by transitions to other tonalities and a harmonious interaction of voices. The second part, written as a chorus fugue, is impeccable in counterpoint technique, modulation plan, and general architectonics. It is no accident that the "Plotiyu usnuv" remains until today one of the most popular and often performed sacred works of B. Galuppi, written based on the Church Slavonic texts.

Manuscripts of three B. Galuppi's concerts ("Gotovo serdtse moye, Bozhe”, "Sudi, Gospodi, obidyashchiye mya” и "Uslyshit tya Gospod'”) are contained in the already mentioned collections of the last quarter of the XVIII century from the Berlin Singing Academy (all three concerts, voice parts, anonym), the Vienna Court Singing Chapel (the concert "Uslyshit tya Gospod'”, part indicating the author) ${ }^{26}$, the Yaroslavl Kazan Nunnery (the concert "Uslyshit tya Gospod'”, vocal parts, anonym, see footnote 20) and in the voice book with bass parts remained from once-complete set (concert "Uslyshit tya Gospod'”, bass, anonym, see footnote 22). These manuscripts should be added with an incomplete set of voice books belonging to the same period with the anonymous parts of all three Galuppi's concerts ${ }^{27}$ [11, p. 171-172].

In his sacred concerts written for the Russian Orthodox Church, the Italian maestro proposed a new music-style model, which in structure and musical language was fundamentally different from the traditional songs of the concert genre. B. Galuppi used as a basis the traditions of Western European sacred music and modern achievements of the Venetian concert school, well known to him by his work as a conductor in the Cathedral of San Marco in Venice. It was this model that received the status of classical and was subsequently established in the musical culture of the Russian Orthodox Church. The new concerts musical language have no trace remained of the former baroque heaviness, and the basis of the composition was, according to Galuppi himself, the "elegance, clarity, and good modulation" ("vaghezza, chiarezza e buona modulatione”) [2, p. 87].

${ }^{25}$ Pölchau Mus. ms. 2305.

${ }^{26}$ ÖNB, HK. 3086/2 (A Whk - VII/397).

${ }^{27}$ Glinka All-Russian Museum Association of Musical Culture, f. 283, № 172, 882 (alto), 884 (tenor). 


\section{Orthodox Church music in the creativity of G. Sarti}

Giuseppe Sarti (1729-1802) is another composer who came to Russia from Italy and worked fruitfully to create a repertoire for the Russian Orthodox Church. This musician stayed in the Russian Empire much longer than B. Galuppi (1784 - 1801), and served not only in the imperial court, but also in private chapels of wealthy aristocrats, for example, Prince G. A. Potemkin (1787-1791).

G. Sarti wrote much more for the Russian Orthodox Church than his predecessor B. Galuppi. This is due to the fact that Sarti spent more time in Russia, and the fact that he arrived at a time when a new style of sacred music was already established in full.

Like Galuppi, Sarti wrote in different genres of church music. He created simple everyday songs, and virtuoso choral concerts. Sarti's choir compositions created based on the liturgical texts also sounded outside the church, for example, during holidays and secular ceremonies. In general, compared with the simplicity and elegance of Galuppi's church music, Sarti's works are considerably complicated, diverse in singing compositions, texture and form, and the musical language reflects the mass, representative nature of the cultic action, which sometimes goes beyond the church rite and acquires secular nature. Sarti reworked quite often his sacred concerts in cantatas, adding them with the orchestral accompaniment, which Galuppi did not do.

We will start to describe G. Sarti's sacred and musical heritage with the Orthodox liturgy. It is mentioned in the same sale announcement of music texts in H. Gene's store in Moscow, as B. Galuppi's sacred works ${ }^{28}$. The announcement states that it is written for two choirs. This liturgy was not found as complete cycle in any of the sources, however, in the manuscript and printed collections of the XIX and early XX centuries there are its separate parts "Slava Otzsu i Synu” C-dur ${ }^{29}$, "Priidite, poklonimsya” g-moll ${ }^{30}$, “Heruvimskaya” D-dur (№1) and Es-dur (№2) ${ }^{31}$, “Veruyu” G-dur ${ }^{32}$, “Dostoyno

${ }^{28}$ Moscow Gazette, 1804, №80, 5 October.

${ }^{29}$ It is given in the Catalogue of the Singing Music Texts with D. Bortnyansky's authorship; twice published at the beginning of the XX century, see: [5, p. 510].

${ }^{30}$ This part is known only from handwritten sources: Glinka All-Russian Museum Association of Musical Culture, f. 283, № 128 (score, with the author's name); Glinka All-Russian Museum Association of Musical Culture, f. 283, № 38 (alto, anonym).

${ }^{31}$ Both Cherubim were published in the early XX century in the collection of "Historical Reader of Church Singing” (edited by St. Mary Lisichin, Issue II, Book Publishing House of P.K. Seliverstov, [1903-1904]). Cherubim No. 1 was reprinted in the 90s.

32 Known only from handwritten sources: Glinka All-Russian Museum Association of Musical Culture, f. 283, № 128; Glinka All-Russian Museum Association of Musical Culture, f. 283, № 38 (in tonality A-dur). 
yest"” A-dur ${ }^{33}$, “Tebe poyem” e-moll ${ }^{34}$ and "Otche nash” F-dur ${ }^{35}$. Some of them are written for a double composition ("Priidite, poklonimsya”, "Veruyu”, "Tebe poyem”, "Otche nash”), some are later one-choir arrangements.

Some liturgy parts have a particularly solemn character. Their musical phrases are based on fanfare intonations and require a rich sound. This refers to the first part "Slava Otzsu i Synu": on the background of a sustained tonic sounding in the basses and tenors, the high voices sing a theme resembling a real trumpet fanfare. In the orchestra, this phrase could be assigned to two trumpets, and it would sound bright and inviting. A successful combination of intra-syllabic chant and textual recitation is formed between the pairs of high and low voices.

These trends associated with the creation of a representative, affective manner of choral writing, are repeatedly reinforced in G. Sarti's sacred concerts written for a variety of singing compositions. Most of them are mentioned in the registry of Count N.D. Sheremetev's music texts library, compiled in the 30s40 s of the XIX century ${ }^{36}$, separate compositions are indicated in the Catalogue of the Singing Music Text of 1793 and music texts sale announcements (Moscow Gazette for 1804, No. 80 dated 5 October; St. Petersburg Gazette for 1822, No. 23 dated 21 March). Some concerts were published by the Court singing chapel in the 10-s years of the XIX century and were subsequently reprinted; some were published for the first time at the beginning of the XX century. In total it is known about G. Sarti's 12 concerts, from which there are music texts of 8 concerts, all - in score record:

1) "Zryashche mya bezglasna" a-moll, for 5 voices, in three parts ${ }^{37}$;

2) "Nyne sily nebesnyye” g-moll, 6 voices (two soprano, two tenors, alto, bass), in three parts ${ }^{38}$;

3) “Otrygnu serdtse moye” D-dur, 6 voices (two soprano, two alto, tenor, bass), in five parts ${ }^{39}$;

${ }^{33}$ The music text of this part was not found; incident of the soprano part is given in the Catalogue of Singing Music Texts, № 93.

${ }^{34}$ Known only from handwritten sources: Glinka All-Russian Museum Association of Musical Culture, ф. 283, № 117; Glinka All-Russian Museum Association of Musical Culture, f. 283, № 119 (one-choir arrangement).

${ }^{35}$ This chant was repeatedly published throughout $1890-1916$, see: [5, p. 509].

${ }^{36}$ RSHA, f. 1088, оп. 3, № 1732 .

${ }^{37}$ Handwritten option: МГК, X-41078 (collection of the end of the XIX century).

${ }^{38}$ Handwritten option: Glinka All-Russian Museum Association of Musical Culture, f. 283, stor. It.. 42. Editions: SPb, 1817-1818 (at D. Bortnyansky's initiative); sacred and musical compositions of different authors. Series 3. M., Jurgenson, cens. 1880; The church-singing collection, vol. III, part 1. St. Petersburg, Sin. type., 1902.

${ }^{39}$ Handwritten option: RNL, f. 1021, d. 1, №2. Edition: Historical reader of church singing, ed. saint. M. A. Lisikina. Issue. II. Ed. Book-musical. shop P.K. Seliverstov, [1903-1904]. 
4) "Pomiluy mya, Bozhe” f-moll, for 4 voices (referred to as eightvoiced), in nine parts ${ }^{40}$. This concert is a simplified version of G. Sarti's Latin oratorio "Miserere" and is known as a cantata, with orchestral voices ${ }^{41}$;

5) "Priidite, vospoim lyudiye" C-dur, for 4 voices (referred to as eightvoiced), in four parts ${ }^{42}$;

6) "Raduytesya, lyudye” D-dur, for 4 voices, in four parts ${ }^{43}$;

7) "Slava v vyshnikh Bogu” G-dur, 4 voices, in five parts ${ }^{44}$;

8) “Tebe Boga khvalim” D-dur, for 4 voices (sometimes - for 8 voices), in four parts ${ }^{45}$. This concert was written for a purely secular occasion (a celebration on the occasion of the capture of the Ochakov Fortress by Russian troops in December 1788) and is a simplified version of G. Sarti's Latin oratorio "Te Deum"46.

The most important feature of G. Sarti's choral concerts is the texture: ratio of the singing parts reminds us not the chorus score, but the orchestral presentation, with the homophonic make up prevailing over the polyphonic one. Note also that the performance of choral concerts on especially solemn occasions was accompanied by a bell-ringing and cannon firing. All this required massive sound and great singing compositions, so the choir sometimes included up to 300 persons. All this was radically different from the elegance of B. Galuppi's sacred works style. "Sarti loved expressive and catchy intonations, volume, and richness of sound. His compositions caused enthusiastic excitement among listeners, high joy of communicating with the outstanding master - heir of the age-old musical art traditions of his country", M. Rytsareva noted [7, p. 147].

${ }^{40}$ Mention: Singing Music Texts Catalogue, No. 96 (as eight-voiced). Handwritten option: Collection of sacred concerts from Archimandrite Matthew's Collection (Sergiyev-Posad).

${ }^{41}$ Handwritten option: GB-Lbl, Add. 24288 (late XVIII century manuscript).

${ }^{42}$ Handwritten option: MSC, X-41415 (late XIX century manuscript).

${ }^{43}$ This concert was published several times during the period of 1093-1914. For a list of collections, see: [5, p. 501] and was copied into a handwritten collection of sacred concerts from Archimandrite Matthew's Collection (Sergiyev-Posad).

${ }^{44}$ Handwritten option: Glinka All-Russian Museum Association of Musical Culture, f. 283, sing. hr. 127. Edition: Historical reader of church singing, ed. M. Golitsyn. Issue. XI. St. Petersburg., 1902.

${ }^{45}$ Handwritten options: MSC, X-41398 (8 голосов); MSC IV-17198; MSC, reading room, E-670; RNB, f. 1021, d. 3 (1), No. 2; Collection of sacred concerts from Archimandrite Matthew's Collection (Sergiyev-Posad).

${ }_{46}$ Mentioned in the register of church concerts given in Moscow in 1796 (GMM, Department of Written Sources, 83, No. 158, sheet 65), see: [5, p. 503-504]. 


\section{Reception of Orthodox music of Italian composers in sacred concert "Ne otverzhi” by M. Berezovsky}

The subject of the article partly pretends to be sensational, since the question of editions of choral works by Maxym Berezovsky (1745-1777) has never been raised, moreover, nothing was known about any author's or poster editorials. For many years we have all studied choral works by Berezovsky in a collection of $1989^{47}$. In the introductory article of this collection, the sources of the musical text of all compositions are indicated - the printed editions of the $\mathrm{XIX}$ and the beginning of the XX century, as well as handwritten copies of the late XIX century.

As we see, the material that has become the basis for publication, has no direct relation to the Berezovsky era, but represents later periods. At the same time, the handwritten materials of the XVIII century, including the lifelong ones, which also contain the texts of Berezovsky's published works for the choir, have survived.

Studying these sources and comparing handwritten and published variants has led to unexpected results. In practically every published work, traces of the later editorial changes were discovered, which, to varying degrees, changed the original author's text. Changes cover different levels: in one case the tonality changes, the form is corrected in the other, the voice is in the third, the harmony in the fourth, the invoice in the fifth, etc.

As an example, we will consider the textbook and the well-known example of Berezovsky's work - the choir concert "Ne otverzhi mene vo vremia starosti" (hereinafter - the Concert). It refers to the peak events in the Ukrainian musical culture of the second half of the XVIII century. It has been for a long period of time the only preserved composition by M. Berezovsky in the concert genre and gave an idea of not only his work, but the composer's fate as well. It was republished and often performed, and today, it has a strong presence in the curriculum and concert repertoire, and the leading musicologists, authors of works on M. Berezovsky's life and creative work were studying it.

All Concert publications are identical in terms of the note text reproduction and, as indicated in one of the collections, are based on the edition of the Court Chapel of $1842^{48}$, which, in its turn, is based on the text of edition 1817-1818 (List of all publications of the Concert [5, p. 26-27]). Consequently, the known to us Concert version, which is unquestionably considered the author's one, was published 40 years after M. Berezovsky death.

\footnotetext{
${ }^{47}$ Березовский М. (1989) Хоровые произведения, сост., ред., вступ. статья М. Юрченко. К.: Музична Україна, 112 с.

48 История русской музыки в нотных образцах (1968), под ред. С.Л. Гинзбург, 2-е изд, Т. 1., М.: Музыка, с. 486.
} 
The Concert is also found in manuscript collections of an earlier origin, including of the lifetime, which date back to the last decades of the XVIII century, and therefore contain the note text not from the first edition, but from other sources, possibly ascending to autograph. The most famous list is the British manuscript of the late XVIII century, which contains the four-voice score of the Concert ${ }^{49}$.

The musicologists who studied this manuscript noticed that its note text in some details does not coincide with the well-known published sample. Thus, V. Vitvitsky in his book about M. Berezovsky, published in 1974 in New Jersey, indicated that the British list of the Concert "Ne otverzhi" does not distinguish between the first and second voices, and the four-voiced voice is more compact [4, pp. 47? 53]. M. Rytsareva, when comparing the note text of the British manuscript with the publication by P. Jurgenson (1890), detected "a large number of misunderstandings concerning individual notes, durations, a number of divizi, dynamic indications, etc." and suggested that "the source of discrepancies could consist not only of the concert editing at publication, but in another version of the manuscript of the XVIII century as well” [8, p. 131].

The information reported was based on the study of the British manuscript alone and was perceived as a minor fact, explained by the rather common tradition of making changes to the newly created lists. They don't provide for the representations about the true state of affairs, as well as the causes and consequences of the phenomenon described. And only the reference to other manuscripts containing the text of the Concert and study of this text made it possible to establish that the discrepancies found are not accidental. The discovery of differences between handwritten and printed variants and the determination of the reasons of this phenomenon is the purpose of the study.

In addition to the British manuscript, the Concert lists were identified in two manuscripts:

1) the collection of the spiritual works by B. Galuppi and M. Berezovsky, maintained with the Central State Archive-Museum of Literature and Art of Ukraine (Kiev) and dates back to the 70-ies of the XVIII century ${ }^{50}$;

2) the collection of choral concerts of the end of the XVIII century from Russian national Museum of music ${ }^{51}$.

Same as with the Concert publication, all three lists were identical in the reproduction of the note text, with the exception of the fixation form - scores in the British manuscript and voice-part in Kiev and Moscow collections, with the differentiation of choral parts for soloists and ripienists. This allowed us to

\footnotetext{
${ }^{49}$ British Library, London, Add. 24288, f. 97r.-114 r.

${ }^{50}$ F. 441, № 907, concert № 13.

${ }^{51}$ F, 279, №oo 937 - soprano I, 172 - alto I, 882 - alto II, 884 - tenor II, concert № 26.
} 
assume that the discrepancies between the manuscript and published versions are systemic, and their comparative analysis provided the absolutely unexpected results, since not only revealed the materiality of the discrepancies, but also sowed grains of doubt in the authenticity of certain sections of the Concert wellknown version unconditionally accepted by us as original.

What is the original author's version and why did another one appear that we consider original?

Before giving answers to both questions, it should be noted that both M. Berezovsky's biography and work are obscured for some reason, and that the process of "plunging into oblivion" began, apparently, as early as back in the XVIII century. We can say that "Ne otverzhi" Concert was lucky, because contemporaries showed their interest in it. This is evidenced, in particular, by Count V.G. Orlov's letter to I.A. Fursov (1787): "Visit Dmitriy Stepanovich [Bortnyansky] and notify me, who composed the "Ne otverzhi mene" Concert. He wrote to me that this is not his work" [3, p. 327].

We will get back to the role of $\mathrm{D}$. Bortnyansky mentioned in the letter in the matter of preserving and popularizing the M. Berezovsky's "Ne otverzhi" concert, and now let us turn to the observations over the note text of the Concert manuscript. The first fundamental difference is the interpretation of solo ensemble constructions in the first three parts. As is known, in the published version, most ensembles are three-voiced and inherit the features of a cantilever texture, and the divizi principle of choral parts, already mentioned in M. Rytsareva and V. Vitvitsky publications, is used to create a three-part voice.

There is nothing like this in the manuscript version. All solo-ensemble constructions of I, II and III parts are fundamentally two-voiced, and divizi is not even supposed, aside of absence at all. It is not present in other choral works by $\mathrm{M}$. Berezovsky, therefore, the third voice is introduced artificially here, in order to comply with certain principles of organization of the texture, which were established in choral concerts of a later period.

Let's consider the phenomenon noted on specific examples and we will start with the analysis of the I part solo-ensemble constructions. Thus, the first three-voice is formed here in the second pair of expositions of the theme (altsoprano), to which one more voice is added - the first soprano (vols. 5-10). In melodic terms this voice is absolutely not developed, however, with its active participation, sharp-dissonant harmonious consonances, which are absent in the manuscript version of the Concert, are created. Another consequence of adding a third voice is the change in the melodic relief of the theme when it is performed with soprano voice: to create the three-voiced chord structures it was necessary to "immolate" the high sixth stage (B-natural sound was replaced with B-flat) followed by the expressive ascending quart jumps, and to transfer the ending of the theme to an additional third voice, contenting with an 
intonationally neutral movement over the tones of chord accords. Such a violation of the linearity of voice principle is not characteristic of Concerto manuscript version, where the second pair of themes is derived from the first pair (bass - tenor) and repeats exactly the original two-voice combination with no intonational transformations and additional counterpoints; only the altitude position changes, in accordance with the range of a new pair of singing voices.

All subsequent paired performances of the Concert I part in the manuscript version are also derived from the initial two-part combination in bass and tenor parts. They are based on the principles of direct and opposite voices rearrangement in the double counterpoint of the octave, and, embracing the traditional circle of tonalities (a-moll, F-dur, d-moll), contain nothing, but the actual theme. In the same version, an additional voice is getting involved to each paired statement, transforming a two-part polyphonic combination into a three-voiced chord. Each time this voice comes in imitation, with an interval of one cycle as failed statement, and in one of the combinations even begins to present the theme, which leads to an intonational adjustment of one of the main voices (see vols. 32-34, statement in F-dur tonality).

By the same principle, the links between the blocks are changed (the latter are formed by solo-ensemble statements and choral interludes). In the manuscript version the links are arranged uniformly. These are short two-voiced constructions based on a common thematic material and repeated in different pairs of voices (tenor-bass, alto-tenor, alt-bass, and soprano-alt) with a change in altitude, depending on the tonal plan of the theme. In the published version, both the number of voices and material distribution between them varies arbitrarily: the first link turns out to be a three-part (second tenor is added), the second and third are two-voiced, and the fourth is four-voiced (all the choral parts are involved).

Thus, the introduction of additional voices breaks the perception of the repetitive constructions as derivatives of the original contrapuntal combinations, which are undoubtedly conceived as two-voiced and organizing sections of a large imitation-polyphonic composition into a single integrated structure.

Even more changes are found in the third part of the Concert. Since it is dominated by a solo-ensemble presentation, the overwhelming majority of thematic constructions undergo editing, which fundamentally changes the textural weaving of musical tissue.

So, in the initial exclamation "Bozhe moj!” ("My God!”), harmonized with the $\mathrm{T}-\mathrm{D}-\mathrm{T}$ idiom, with the distribution of chord tones between the three voices (alt - tenor - bass), the material from the alt part is moved for some reason to the second tenor missing in the manuscript version. The ensemble of two tenors and bass continues further (vols. 124-129); the functional-harmonic certainty of each chord is preserved throughout the construction structurally similar to the first sentence of the period, and the sharpness of the second 
combinations in $D_{7}$ is emphasized, as well as the reduced quints and septims in the double dominant chord.

The manuscript is limited to a tenor and bass voices duet, based on the material from the second tenor and bass parts. It is curious that the harmonically arranged middle voice from the three-voice version is transformed here into a full-fledged melodic line, and the interval accords formed between the voices repeat the idioms already encountered in the paired statements from Part I of the Concert.

Such transformations occur in the subsequent construction, which in the manuscript version is a two-voiced canonical imitation in the parts of the alt and soprano, which follows from the top-source and resembles the so-called golden sequel, well-known for instrumental concerts of the Baroque Era; in the printed version, the imitation parts in proposta are veiled by adding a second alt that creates unison, seconds combinations and tertiary duplications of the original voice. Also, there is a correction of the intonational relief of each of the voices, which transforms the two-part counterpoint into accordion-harmonic structures and is especially noticeable in the melodic cadence, which concludes the III part solo-ensemble section.

The only two-voiced construction of the Concert II part (alt-bass, vols. 53-63) also turned out to be transformed into a three-voice as a result of doubling the bass voice into the upper third.

The second fundamental difference between the manuscript and published versions of the Concert is associated with the use of accidentals, which in some cases are added, and in others - removed. The addition of accidentals occurs in the overwhelming majority of cases in the chords of the subdominant group used in S - D idioms, which leads to their transformation into a double dominant, and also while transfer from the tonic to subdominant in minor keys, which creates the effect of a short-term transition to a new tonal centre. Consequently, M. Berezovsky's harmonic innovations, referred to by many modern researchers, are the result of a later editorial revision.

Summing up our observations, we would like to note that M. Rytsareva's assumption expressed in the book about M. Berezovsky turned out to be true: the Concert editing was indeed performed, but not for P. Jurgenson's publication, but for the first edition of 1817-1818, the note text of which was reproduced without modification in subsequent publications and considered today as genuine. Concert manuscript lists, including British manuscript studied by M. Rytsareva, in fact contain another version of the note text, which is not virtually known today. In all likelihood, this version is the original author's version of "Ne otverzhi" Concert, and the various readings are more significant, since they are not limited to external manifestations, but affect the deep compositional level. 
D. Bortnyansky's note archive answers the question regarding person who performed the editing, or rather the register of this archive, compiled after composer death by his widow Anna Bortnyanskaya (Russian State Historical Archive, SPb., f. 499, in. 1, 1827, №. 82). M. Berezovsky's Concert "Ne otverzhi mene vo vremia starosti" is listed in the register in section "[Works] of different writers, re-corrected", which indicates directly the editorial corrections by D. Bortnyansky, introduced by him for the publication of 1817-1818. Specific features of the changes introduced, in particular, the use of the divizi technique, which is very characteristic of D. Bortnyansky's choir concerts, also indicates his participation in this process. Therefore, we mistakenly consider the version edited by D. Bortniansky as the Concert original.

Fortunately, the editorial corrections did not affect the choral parts of the Concert. Magnificent, masterly written large polyphonic sections (fugato "Pozhemite i imite jeho" from the II part and famous final fugue "Da postydjatsja”) are undoubtedly issued from the true Master's pen, and convince us that M. Berezovsky's creative heritage needs only one thing - most rapid return from oblivion.

\section{CONCLUSIONS}

B. Galuppi and G. Sarti creative activity in the Russian Empire played an important role in the emergence and adoption of the Orthodox church music new style, which had long needed to be reformed. In Europe, this side of the Italian composers work is little known, and the works themselves do not enjoy special performing demand and are circumvented by listener's attention.

The information sources of the second half of the XVIII century include the references to the fact that other Italian kapellmeisters invited to Russia also wrote music for Orthodox worship (J. Astarita, V. Manfredini, T. Traette, A. Sapienza, etc.). Their works are not found. If they were written in due time, they probably did not become as popular as B. Galuppi and G. Sarti's works, and got lost in the general flow of music products, the amount of which was rapidly growing during the reign of Catherine II.

The great importance of B. Galuppi and G. Sarti's activity in Russia also implies the fact that they became teachers of a new generation of musicians who worked fruitfully to create church music, including in the choral concerto genre. D. Bortnyansky was B. Galluppi's student; A. Wedel and S. Degtyarev G. Sarti's students.

Prospects for studying this topic are to identify the causes and methods of editing the original author's text in all choral works published during the XIX and early XX centuries, as well as in the publication of authentic versions of M. Berezovsky's choral works created by the author and performed during his life. 


\section{SUMMARY}

The main characters of the article are well-known Italian composers of the second half of the XVIII century - Baldassare Galuppi (1706-1785) and Giuseppe Sarti (1729-1802), who worked in the capital and other major cities of the Russian Empire during the reign of Catherine II (1762-1796). The main purpose is to show that Italian musicians who did not speak Russian worked a lot and fruitfully to create sacred music for Church Slavonic texts intended for the Orthodox Church and left a rather significant creative heritage in this area of musical activity. An overview is provided of handwritten and printed sources containing art works of B. Galuppi and G. Sarti. Particular attention is paid to the issue of "italianization" of the sacred music style of the second half of the XVIII century. The foundations of this process were laid by Italian composers invited to Russia, whose duties included writing not only secular but also church music. The newest style was mostly embodied in the genre of a choral concert, as evidenced by an analysis of the sacred works by B. Galuppi, G. Sarti and M. Berezovsky.

\section{REFERENCES}

1. Antonenko YE. (2012) Galuppi i russkaya dukhovnaya muzyka [Galuppi and Russian sacred music]. Bulletin of the Moscow Conservatory, vol. 2, pp. 34-67. (in Russian)

2. Burney Ch. (1961) Muzykal'nyye puteshestviya: Dnevnik puteshestviya 1770 g. po Frantsii i Italii [Musical Travels: Travel Diary of 1770 in France and Italy]. Leningrad: Muzgiz. (in Russian)

3. Orlov-Davydov V. (1878) Biograficheskiy ocherk grafa Vladimira Grigor'yevicha Orlova, sostavlen vnukom yego, grafom Vladimirom OrlovymDavydovym [Biographical sketch of Count Vladimir G. Orlov, compiled by his grandson, Count Vladimir Orlov-Davydov], t. 1. St. Petersburg: Tipografiya Imperatorskoy Akademii nauk. (in Russian)

4. Vytvyts'kyy V. (1974) Maksym Berezovs'kyy: Zhyttya i tvorchist' [Maxim Berezovsky: Life and Work]. Jersey City: Vyd-vo M.P.Kots'. (in Ukrainian)

5. Lebedeva-Yemelina A. (2004) Russkaya dukhovnaya muzyka epokhi klassitsizma (1765-1825). Katalog proizvedeniy [Russian sacred music of the era of classicism (1765-1825). Catalog of works]. Moscow: ProgressTraditsiya. (in Russian)

6. Porfir'yeva A. (2000) Galuppi Bal'dassare [Galuppi Baldassare]. Musical Petersburg: Encyclopedic Dictionary, 18th century, book 1. St. Petersburg, pp. 226-232. (in Russian) 
7. Rytsareva M. (2006) Dukhovnyy kontsert v Rossii vtoroy poloviny XVIII veka [Sacred concert in Russia in the second half of the XVIII century]. St. Petersburg: Kompozitor. (in Russian)

8. Rytsareva M. (1983) Kompozitor M. S. Berezovskiy: Zhizn' i tvorchestvo [Composer M.S. Berezovsky: Life and Work]. Leningrad: Muzyka. (in Russian)

9. Shtelin YA. (1935) Izvestiya o muzyke v Rossii [News of music in Russia]. Leningrad: Triton. (in Russian)

10. Shumilina O. (2016) Prychasni virshi M.Berezovs'koho: oryhinal chy piznisha pidrobka? [Communion's verses of Maxim Berezovsky: original or later imitation?] Journal of the Tchaikovsky National Academy of Music of Ukraine, vol. 4 (33), pp. 25-37. (in Ukrainian)

11. Shumilina O. (2012) Styl'ova dynamika ukrayins'koyi dukhovnoyi muzyky XVII-XVIII stolit' (za materialamy rukopysnykh kolektsiy) [Style dynamics of Ukrainian sacred music of the 17th-18th centuries (based on the materials of manuscript collections)]. Donetsk: Bravo. (in Ukrainian)

Information about the author:
Shumilina O. A.,
orcid.org/0000-0002-2615-1208

Docent, dr hab.,

Professor at the Department of the Theory of Music,

M. Lysenko Lviv National Musical Academy

5, Nihankivskoho str., 79005, Lviv, Ukraine 